\title{
Water Development Schemes in the United States*
}

$\mathrm{T}$ HE National Resources Committee of the United States Government, the membership of which includes the Secretaries for the Interior, for War, for Agriculture, for Commerce and for Labour, has issued an important document on "Drainage Basin Problems and Programs (1937 Revision)", which has been prepared by the Water Resources Committee with the co-operation of local, State, regional and federated organizations. It is a comprehensive review of suggestions emanating from forty-five Drainage Basin Committees, themselves nominated by "Governors and State Planning Boards, including field men from interested Federal bureaus". It will thus be seen that the recommendations are based on a widespread representation of national interests.

The report was commissioned by the President and constitutes a revision of the report to Congress on February 3, 1937, rendered necessary by recent developments, including fresh problems and new standards of treatment. An amended programme, accordingly, has been prepared, covering a series of specific projects to be undertaken within a 2-6 year period, at an estimated cost, amounting in the total to $891,091,000$ dollars, with a "weighted average" per year of $200,624,000$ dollars. This weighted annual average compares with more than $180,000,000$ dollars recommended in the President's 1939 Budget for the same classes of work. During the last six years, the Federal Government has expended more than $1,300,000,000$ dollars on works of a similar character.

Foremost in the report comes the subject of flood control, which in the United States is a matter of the most serious public concern. One has only to recall the devastation and loss of life caused during the floods of recent years in the Mississippi and Ohio river valleys to realize how vital this matter is to a vast mass of the population. Unfortunately, the problems involved are so complex that, as yet, they are inadequately explored, and it is felt that it would be most unwise to authorize any additional general flood control plan until more trustworthy information is obtained. An early inauguration of surveys and investigational studies of a comprehensive character is urged and budgeted for at a cost exceeding 260 million dollars.

The reclamation for agricultural purposes of extensive regions of arid and semi-arid country requires continued attention. Works are already

*Drainage Basin Problems and Programs, 1937 Revision. (National Resources Committee, Washington, D.C.) Pp. $\mathrm{x}+154+4$ plates. (Washington: Gov. Printing Office, 1938.) 65 cents. authorized and in hand to the extent of upwards of $600,000,000$ dollars, but further surveys are needed for future planning and development. West of the 100th meridian, there is a vast domain of no fewer than 700 million acres where agriculture can make no progress without artificial irrigation. The outlay required is put at nearly 300 million dollars. Problems of flood control policy naturally involve a consideration of the allocation of cost among the various scattered communities in lowlying regions subject to inundation, in fair proportion to the incidence of benefit and of ability to pay, and this is a matter which can only be settled by prolonged negotiation.

Water-power is an important consideration in the United States, where there are very considerable reserves ready for exploitation. The energy produced is utilized in many directions for power, heating and lighting. Water-power has within the past half century furnished 3-4 per cent of the total energy derived alike from mineral fuel and water, and the report states that "despite the fact that the nation now depends and in future must depend largely on its fuel resources, its water power is of great value and presents great opportunities in the co-ordinated development of water resources". Some of the more important undertakings in hand, as the Boulder Dam on the Colorado River, the Bonneville and Grand Coulee Dams on the Columbia River, and the series of developments in the Tennessee Valley have already been described in NATURE $(139,738,823,986$; 1937.)

The other subjects dealt with in the report, which runs to more than 150 pages, are so many and so varied that it is not practicable to touch upon them all within restricted limits of space. A mere enumeration shows that they include navigation, soil conservation, beach erosion control, projects for agriculture and grazing, pollution, recreation and wild-life, hydrological data and investigations, and multiple-purpose projects.

The report concludes with an expression of the conviction of its members that "a National Planning Agency should have as one of its chief duties the continuous development of broad plans for full use of our water resources in relation to human needs and social objectives". This clear and explicit declaration of policy might with advantage be adopted in other countries, and every credit is due to the United States for setting so conspicuous an example of enterprise in the exploitation of its own supplies. 